\title{
Efek Komunikasi dalam Organisasi Karang Taruna
}

\author{
Agus Baihaqi, Rizqi Martino \\ IAI Darussalam Blokagung Banyuwangi \\ Email : agusbaihaqi@iaiida.ac.id ${ }^{1}$, rizqimartino@gmail.com ${ }^{2}$
}

\begin{abstract}
This research is motivated by the fact that every random organization also has its own character or culture. Likewise with the youth organization, the youth army of Sasak Cemeng. This research examines the effect of communication on the youth organization, the youth army of Sasak Cemeng, Karangmulyo village. This type of research uses qualitative methods using data from observations and interviews with informants. The informants in this study amounted to 5 people with the criteria that they were registered as official members of the youth organization Sasak Cemeng youth organization. The result is the communication of the youth organization, the youth group Sasak Cemeng, the Karang Taruna Organization is an organization that stands from the West Sumberkembang Hamlet youth movement which has the aim of strengthening the ties of brotherhood with routine activities which are held every two weeks, once a month and once a year this is in line with a statement that the community or organization is a form of cooperation between several people to achieve a goal by holding division and work regulations.
\end{abstract}

\section{Keywords: Communication Effects, Organization, Karangtaruna}

\begin{abstract}
Abstrak
Penelitian ini dilatar belakangi kenyataan bahwa setiap organisasi dalam random pun juga memiliki karakter atau kebudayaan masing-masing. Begitu pula dengan organisasi karang taruna laskar pemuda sasak cemeng. Penlitian ini mengkaji mengenai Efek Komunikasi pada organisasi karang taruna laskar pemuda sasak cemeng desa karangmulyo. Jenis penelitian ini menggunakan metode kualitatif dengan menggunakan data dari observasi dan hasil wawancara dengan informan. Adapun informan dalam penelitian ini berjumlah 5 orang dengan kriteria telah tercatat sebagai anggota resmi organisasi karang taruna laskar pemuda sasak cemeng. Hasilnya adalah Komunikasi organisasi karang taruna laskar
\end{abstract}

54 | Efek Komunikasi Dalam Organisasi Karang Taruna Agus Baihaqi, Rizqi Martino 
pemuda sasak cemeng, Organisasi Karang Taruna adalah Organisasi yang berdiri dari gerakan pemuda Dusun Sumberkembang Barat yang mempunyai tujuan mempererat tali persaudaraan dengan kegiatan-kegiatan rutinan yang diselenggarakan dua minggu sekali, satu bulan sekali dan setahun sekali hal ini senada dengan pernyataan bahwa Komunitas atau organisasi merupakan bentuk kerjasama antara beberapa orang untuk mencapai suatu tujuan dengan mengadakan pembagian dan peraturan kerja.

\section{Kata kunci: Efek Komunikasi, Organisasi, Karangtaruna}

\section{A. Pendahuluan}

Manusia di dalam kehidupannya harus berkomunikasi, artinya memerlukan orang lain dan membutuhkan kelompok atau masyarakat untuk saling berinteraksi. Hal ini merupakan suatu hakekat bahwa sebagian besar pribadi manusia terbentuk dari hasil integrasi sosial dengan sesama dalam kelompok dan masyarakat. Di dalam kelompok ataupun organisasi, selalu terdapat bentuk kepemimpinan yang merupakan masalah penting untuk kelangsungan hidup kelompok, yang terdiri dari atasan dan bawahannya.

Di antara kedua belah pihak (atasan dan bawahan) harus ada two way communications atau komunikasi dua arah atau komunikasi timbal balik, untuk itu diperlukan adanya kerja sama yang diharapkan untuk mencapai cita-cita, baik cita-cita pribadi, maupun kelompok, untuk mencapai tujuan suatu organisasi. Kerjasama tersebut terdiri dari berbagai maksud yang meliputi hubungan sosial maupunkebudayaan. Hubungan yang terjadi merupakan suatu proses adanya suatu keinginan masing-masing individu, untuk memperoleh suatu hasil yang nyata dan dapat memberikan manfaat untuk kehidupan yang berkelanjutan.

Hubungan yang dilakukan oleh unsur pimpinan antara lain kelangsungan hidup berorganisasi untuk mencapai perkembangan ke arah yang lebih baik dengan menciptakan hubungan kerja sama

55 | Efek Komunikasi Dalam Organisasi Karang Taruna Agus Baihaqi, Rizqi Martino 
dengan bawahannya. Hubungan yang dilakukan oleh bawahan sudah tentu mengandung maksud untuk mendapatkan simpati dari pimpinan yang menupakan motivasi untuk meningkatkan prestasi kerja ke arah yang lebih baik. Hal ini tergantung dari kebutuhan dan cara masing-masing individu, karena satu sama lain erat hubungannya dengan keahlian dan tugas-tugas yang harus dilaksanakan.

\section{B. Kajian Pustaka}

Komunikasi organisasi dapat didefinisikan sebagai pertunjukan dan penafsiran pesan di antara unit-unit komunikasi yang merupakan bagian suatu organisasi tertentu. Suatu organisasi terdiri dari unit-unit komunikasi dalam hubungan hierarkis antara yang satu dengan lainnya dan berfungsi dalam suatu lingkungan. Komunikasi organisasi melibatkan bentuk-bentuk komunikasi antar pribadi dan komunikasi kelompok.

Pembahasan komunikasi organisasi antara lain menyangkut struktur dan fungsi organisasi, hubungan antar manusia, komunikasi dan proses pengorganisasian serta budaya organisasi.

Komunikasi organisasi diberi batasan sebagai arus pesan dalam suatu jaringan yang sifat hubungannya saling bergantung satu sama lain meliputi arus komunikasi vertikal dan horisontal. Bila sasaran komunikasi dapat diterapkan dalam suatu organisasi baik organisasi pemerintah, organisasi kemasyarakatan, maupun organisasi perusahaan, maka sasaran yang dituju pun akan beraneka ragam, tapi tujuan utamanya tentulah untuk mempersatukan individu-individu yang tergabung dalam organisasi tersebut.

Masyarakat desa adalah sejumlah penduduk yang menupakan kesatuan masyarakat dan bertempat tinggal dalam suatu wilayah yang merupakan organisasi pemerintahan terendah langsung dibawah Camat, yang berhak melangsungkan urusan rumah tangganya sendiri 
(Arifin Noor,2007:178) Adapun ciri-ciri masyarakat desa menurut Landis dalam bukunya Rural Life in Process adalah sebagai berikut: (1)Untuk kepentingan statistik, desa merupakan suatu daerah yang berpenduduk kurang dari 2.500, (2)Untuk tujuan analisa psikologi sosial, masyarakat desa mempunyai derajat intimitas dan informalitas yang tinggi. Sedangkan masyarakat kota mempunyai hubungan sosial yang bersifat impersonal. (3)Untuk tujuan analisa ekonomi, pertanian merupakan kepentingan masyarakat.

Dari ciri-ciri diatas point nomer 2 masyarakat desa mempunyai derajat intimitas dan informalitas yang tinggi yang menyebakan terjadinya interaksi sosial. Interaksi sosial merupakan hubunganhubungan sosial yang dinamis yang menyangkut hubungan orangorang perorangan, antara kelompok-kelompok manusia, maupun antara perorangan dengan kelompok manusia. Didalam menelaah masyarakat manusia akan banyak berhubungan dengan kelompokkelompok sosial, baik yang kecil seperti misalnya kelompok keluarga, ataupun kelompok-kelompok besar seperti masyarakat desa, masyarakat kota, bangsa dan lain-lain. Kelompok sosial adalah himpunan atau kesatuan manusia yang hidup bersama, karena adanya hubungan diantara mereka. Hubungan tersebut antara lain menyangkut hubungan timbal balik yang saling memengaruhi dan juga suatu kesadaran untuk saling menolong.

Soerjono Soekanto (2014:118) menjelaskan dalam bukunya tipetipe kelompok-kelompok sosial adalah: (1) Kategori statistik adalah pengelompokan dasar atas ciri tertentu yang sama, seperti kelompok umur. (2) Kategori sosial merupakan kelompok individu yang sadar akan ciri-ciri yang dimiliki bersama, contohnya ikatan dokter. (3) Kelompok sosial, seperti misalnya, keluarga batih. (4) Kelompok tidak teratur, yakni berkumpulnya orang-orang disuatu tempat pada waktu yang sama karena pusat perhatian yang sama. (5) Organisasi formal, 
yaitu setiap kelompok yang sengaja dibentuk untuk mencapai tujuantujuan tertentu dan telah ditentukan terlebih dahulu.

Karena masyarakat desa adalah masyarakat yang paling tinggi derajat intimitas dan informalitasnya maka interaksi sosial terjadi dalam kesehariannya. Sehingga kelompok-kelompok sosial bermunculan sesuai dengan tipe-tipenya masing-masing. Dari masingmasing kelompok ini juga mempunyai peran tersendiri dalam masyarakat. Soerjono Soekanto (2014:2011) Peranan mencakup tiga hal, yaitu sebagai berikut: (1) Peranan meliputi norma-norma yang dihubungkan dengan posisi atau tempat seseorang dalam masyarakat. Peranan dalam arti ini merupakan rangkaian peraturan-peraturan yang membimbing seseorang dalam kehidupan masyarakat. (2) Peranan merupakan suatu konsep tentang apa yang dapat dilakukan oleh individu dalam masyarakat sebagai organisasi. (3) Peranan juga dapat dikatakan sebagai perilaku individu yang penting bagi struktur sosial masyarakat.

\section{Efek}

Efek adalah pengaruh kegiatan komunikasi yang di lakukan komunikator kepada komunikan, sehingga terlihat adanya perubahan yang terjadi dalam diri komunikan. Berdasarkan uraian pengertian komunikasi di atas, maka dapat di simpulkan bahwa pada dasarnya komunikasi itu merupakan proses penyampaian pesan dari seseorang atau kelompok (komunikator) kepada orang lain (komunikan), dengan harapan dapat menimbulkan perubahan sikap dan pendapat dari orang yang menjadi sasaran, komunikasi adalah bentuk interaksi manusia yang saling mempengaruhi satu sama lain, sengaja atau tidak sengaja dan tidak terbatas pada bentuk komunikasi verbal, tetapi juga dalam hal ekspresi muka, lukisan, seni dan teknologi.

a. Jenis-Jenis Efek 
Jenis-Jenis Efek komunikasi massa menurut Keith R.Stamn dan John E Bowes( 1990) membagi menjadi 2 bagian dasar yaitu

1) Efek Primer meliputi terpaan, perhatian dan pemahaman. Efek Primer Dalam komunikasi massa terdapat efek komunikasi yang nyata dan jelas.Jika dalam kehidupan kita sehari hari tidak bisa lepas dari media massa,berarti efek yang di timbulkan nyata terjadi. Secara sederhana efek primer terjadi jika ada orang mengatakann telah terjadi proses komunikasi terhadap objek yang di lihatnya. Yang temasuk di dalam efek sekunder itu adalah perilaku penerima yang ada di bawah kontrol langsung komunikator

2) Efek Sekunder meliputi perubahan tingkat kognitif (perubahan pengetahuan dan sikap), dan peubahan perilaku (menerima dan memilih). Efek Sekunder Efek Kegunaan dan Kepuasaan (Uses dan Gratifications Theory) Ada banyak efek yang di timbulkan oleh saluran komunikasi massa, tetapi dalam efek sekunder untuk melihat kekuatan penagruh komunikasi.Pendapat Swanson Bahwa "Audience" aktif di dalam memanfaatkan media massa.Individu tidak secara spontan dan otomatis merespon pesan pesan media massa. Tetapi individu menggunakan isi media tersebut untuk memenuhi tujuan mereka di dalam usaha menikamti media massa.

\section{Komunikasi}

Istilah komunikasi diadopsi dari bahasa inggris yaitu "communication". Istilah ini berasal dari bahasa latin "communicare" yang bermakna membagi sesuatu dengan orang lain, memberikan sebagian untuk seseorang, tukar menukar memberitahukan sesuatu kepada seseorang, bercakap-cakap, 
bertukar pemikiran, berhubungan, berteman, dan lain sebagainya (hardjana, 2003).

Komunikasi menurut wikipedia adalah proses saling bertukar pikiran, opini, atau informasi secara lisan, tulisan, ataupun isyarat. Proses komunikasi tersebut bisa berupa satu arah maupun dua arah. Komunikasi satu arah dirasakan kurang efektif, karena diantara kedua belah pihak yang sedang menjalin komunikasi hanya ada satu pihak yang aktif, sedangkan pihak lainya bersifat pasif. Sedangkan komunikasi dua arah prosesnya dirasakan lebih efektif karena kedua belah pihak yang sedang menjalin komunikasi sama-sama aktif, karena didalam prosesnya terjadi dialog, yaitu satu pihak berbicara pihak yang lain mendengarkan dan sebaliknya.

Unsur-unsur Komunikasi Menurut Onong Uchjana Effendy dalam buku yang berjudul Dinamika Komunikasi, Unsur-unsur komunikasi adalah:

1 Komunikator (sumber).

2. Pesan.

3. Komunikan.

4. Media atau saluran.

5. Efek.

6. Umpan balik(Effendy, 2004 : 6).

Semua peristiwa komunikasi akan melibatkan sumber sebagai pembuata atau penginim informasi anatarmanusia, sumber bisa terdiri dari satu orang, tetapi bisa juga dalam bentuk kelompok misalnya partai, organisasi atau lembaga.

Pesan yang dimaksud dalam proses komunikasi adalah suatu yang disamapaikan pengirim kepada penerima. Pesan dapat disampaikan dengan cara tatap muka atau melalui media komunikasi. Isinya bisa berupa ilmu penegtahuan, hiburan, informasi, nasehat atau propaganda. Komunikan adalah elemen 
yang penting dalam proses komunikassi, karena dialah yang menjadi sasaran dari komunikasi. Efek adalah perbedaan antara apa yang dipikirkan, dirasakan dan dilakukan oleh penerima sebelum dan sesudah menerima.

Menurut Onong Uchajana Effendy dalam buku yang berjudul Ilmu, Teori dan Filsafat Komunikasi. Tujuan komunikasi adalah :

a. Mengubah sikap (To change the attitude).

b. Mengubah opini (To change the opinion).

c. Mengubah perilaku (To change the behavior).

d. Mengubah masyarakat (To change the society).(Effendy,2003:55).

Sedangkan menurut Gordon I. Zimmeman yang dikutip oleh Dedy Mulyana dalam buku yang berjudul Ilmu Komunikasi Suatu Pengantar merumuskan tujuan komunikasi menjadi dua kategori besar, yaitu :

1. Berkomunikasi untuk menyelesaikan tugas-tugas yang penting bagi kebutuhan.

2. Berkomunikasi untuk menciptakan dan memupuk hubungan dengan orang lain. (Mulyana, 2005 : 4)

Pendapat Keith R.Stamm dan John E.Bowes (1990) Tujuan harus di sesuaikan dengan kebutuhan dan keinginan Individu masing- masing.Jika kebutuhan sudah terpenuhi melalui saluran komunikasi massa berarti individu sudah mencapai tingkat "kepuasaan" Pendapat John R..Bittner Bahwa Fokus utama efek ini tidak hanya bagaimana media mempengaruhi audience tetapi juga bagaimana audience mereaksi pesan- pesan media. Faktor interaksi yang terjadi antara individu akan ikut mempengaruhi pesan yang di terima.

Ada beberapa fungsi komunikasi menurut para ahli diantarannya yaitu : 
a) Thomas M. Scheidel. Menurutnya manusia itu pada umumnya berkomunikasi untuk saling menyatakan dan mendukung identitas diri mereka dan untuk membangun interaksi sosial dengan orang-orang yang disekelilingnya serta untuk mempengaruhi orang lain agar berfikir, merasa, ataupun bertingkah seperti apa yang kita harapkan.

b) Rudolf F.Verderber. menurutnya komunikasi memiliki dua fungsi yakni sosial dan pengambilan keputusan. Tujuan fungsi sosial bertujuan untuk kesenangan, menunjukkan, ikatan, membangun dan memelihara dengan orang lain. Sedangkan fungsi pengambilan keputusan ialah memutuskan untuk melakukan atau tidak melakukan terhadap sesuatu pada saatsaat tertentu.

c) Deddy mulyana (2013:30) dalam bukunya ilmu komunikasi suatu pengantar mengutip kerangka berpikir William I. Gorden mengenai fungsi-fungsi komunikasi yang dibagi menjadi empat bagian. Fungsi-fungsi suatu peristiwa komunikasi (comunikation event) tampaknya tidak sama sekali independen, melainkan juga berkaitan dengan fungsi-fungsi lainnya, meskipun terdapat suatu fungsi dominan.

\section{Organisasi}

Organisasi adalah sebuah wadah untuk sekumpulan orang yang bekerja sama secara rasional serta sistematis yang terpimpin atau terkendali untuk mencapai tujuan tertentu memanfaatkan sumber daya yang ada di dalamnya.

Sementara dalam dunia bisnis, organisasi merupakan sekelompok orang yang melakukan kolaborasi untuk mencapai tujuan secara komersial dengan struktur yang jelas serta memiliki budaya kerja khusus. 
Menurut Maringan (2004) pengertian organisasi dapat dibedakan pada dua macam, yaitu :

a. Organisasi sebagai alat dari manajemen artinya organisasi sebagai wadah/tempat manajemen sehingga memberikan bentuk manajemen yang memungkinkan manajemen bergerak atau dapat dikaitkan.

b. Organisasi sebagai fungsi manajemen artinya organisasi dalam arti dinamis (bergerak) yaitu organisasi yang memberikan kemungkinan tempat manajemen dapat bergerak dalam batas-batas tertentu. Dinamis berarti baa organisasi itu bergerak mengadakan pembagian pekerjaan. Misalnya pimpinan harus ditempatkan di bagian yang strategis. (Mesiono,2010:39)

Hakekat Organisasi menurut Edgar H. Shein dalam bukunya the Psykologi of Organization (1982) organisasi adalah Koordinasi yang direncanakan mengenai kegiatan-kegiatan sejumlah orang untuk mencapai tujuan bersama melalui pembagian kerja dan fungsi berdasarkan tingkatan otoritas (kewenangan) dan tanggungjawab. Dengan definisi ini, pada hakekatnya dalam sebuah organisasi diperlukan sejumlah pesyaratan atau gagasan, antara lain:

a. Bahwa Organisasi memerlukan pengembangan dan pemeliharaan koordinasi.

b. Bahwa didalam organisasi terdapat tujuan bersama yang pencapaianya harus di upayakan semaksimal mungkin.

c. Di dalam Organisasi tedapat pembagian kerja (division of labor)

d. Seluruh kegiatan dalam organisasi harus menciptakan keterpaduan (integration), menekankan bahwa objek 
koordinasi pada dasarnya bukan orang tetapi kegiatan atau pekerjaan.

Dari definisi-definisi diatas dapat disimpulkan bahwa dalam setiap organisasi tendapat tiga unsur dasar yaitu Orang-orang, Kerjasama dan Tujuan yang hendak dicapai. Organisasi juga harus memiliki lima fenomena penting yaitu :

a. Organisasi harus mempunyai tujuan.

b. Organisasi harus mempunyai program, kegiatan strategi dan metode untuk mencapai tujuan organisasi.

c. Organisasi harus mempunyai pimpinan atau manajer yang bertanggung jawab terhadap organisasi itu dalam mencapai tujuan.

d. Organisasi itu terdiri dari dua orang atau lebih.

e. Organisasi itu harus ada kerjasama. (mesiono.2010:40-41)

Organisasi berusaha mempermudah manusia dalam menjalani hidup didunia dengan memanfaatkan segela kelebihan yang terdapat di dalam organisasi. Untuk menyelesaikan masalah, ketika dipikirkan orang banyak, maka segala masalah apapun akan mudah terselesaikan, disbanding satu orang yang memikirkannya. Satu demi satu persoalan akan selesai, tatkala dikerjakan secara gotong royong. Tak salah pepatah mengatakan "berat sama dipikul, ringan sama dijinjing". Faktor penentu terbentuknya onganisasi adalah manusia sedangkan faktor yang berkaitan dengan kerja adalah kemampuan untuk bekerja, kemampuan untuk mempenaruhi orang lain dan kemampuan melaksanakan asas-asas atau prinsip-prinsip organisasi. Chaniago (2011:20)

Manusia adalah makhluk yang dinamis, ketidakterbatasan kebutuhan manusia dan keterbatasan kemampuannya untuk memenuhi kebutuhanya telah menghadapkan manusia untuk hidup berorganisasi. hal ini didukung pula dengan karakteristik manusia 
sebagai makhluk sosial yang tidak memungkinkan hidup wajar tanpa berorganisasi. Organisasi telah dibentuk sejak manusia pertama hidup di muka bumi, sekelompok manusia yang mempunyai orientasi dan tujuan yang relatif sama berhimpun dan berusaha untuk mencapai tujuan tersebut.

Dengan hal tersebut, memang organisasi memiliki arti yang sangat strategis dan peran yang dapat mengelola kehidupan manusia agar lebih mempunyai hakikat yang bermakna. Hakikat organisasi pada dasarnya berorientasi terhadap aspirasi dari pihak-pihak yang memiliki kepentingan terhadap organisasi. Hakikat organisasi menjadi pondasi dasar dan asas dalam pengelolaan organisasi untuk mencapai tujuannya demi terciptanya sistem manajerial yang baik. Dapat dikatakan jika suatu organisasi kehilangan hakikat maka perlu dipertanyakan kontinuitas dari organisasi tersebut.

Lahirnya organisasi akibat adanya tujuan yang ingin hendak dicapai oleh pihak tertentu karena melihat adanya urgensi dari keberadaaan organisasi. Organisasi tidak hanya dibutuhkan pada lingkup yang kecil tetapi juga pada lingkup yang besar terlihat dari motif didirikannya organisasi. Organisasi yang kita ketahui bersama juga memiliki tingkatan tertentu tergantung pada tujuan dan objek dari organisasi tersebut. Contoh dari organisasi yaitu organisasi rumah tangga, organisasi perusahaan, organisasi kemasyarakatan, organisasi kelompok tertentu, organisasi kesamaan keyakinan, organisasi kenegaraan, dan lain-lain.

Oleh karena itu, organisasi memang harus ada di dalam kehidupan manusia sebagai instrumen yang dapat mempersatukan manusia dalam proses dinamika dan keteraturan hidup. Dengan lahirnya organisasi Budi Utomo di Indonesia mengakibatkan lahirnya organisasi-organisasi yang lain yang tentu memiliki tujuan dan sasaran yang berbeda. Organisasi-organisasi tanpa manajemen akan menjadi 
kacau dan bahkan mungkin gulung tikar. Hal ini terbukti dengan jelas dalam situasi yang tidak normal seperti adanya bencana ketika organisasi sedang tidak teratur maka manajemen sangat dibutuhkan untuk membenahi organisasi agar menjadi lebih baik (Dicky, syuhada.2011)

Berikut beberapa tujuan organisasi yang secara umum banyak dijadikan sebagai tujuan dari pembangunan organisasi tersebut yaitu :

a. Meningkatkan kemandirian serta kemampuan dari sumber daya yang dimiliki.

b. Wadah yang digunakan untuk individu yang memang ingin memiliki jabatan, penghargaan serta pembagian kerja yang jelas.

c. Wadah untuk memiliki pengawasan dan kekuasaan.

d. Membantu setiap individu yang ada di dalamnya agar dapat meningkatkan pergaulan serta memanfaatkan waktu luang secara lebih optimal serta bermanfaat.

e. Wadah yang membantu mencari keuntungan bersama-sama dengan kerja sama yang sudah terbagi dengan baik.

f. Membantu untuk pengelolaan lingkungan bersama-sama.

g. Mencapai tujuan secara efektif dan efisien sesuai dengan yang telah menjadi tujuan awal sebuah organisasi.

Organisasi memang harus jelas tujuan serta berbagai hal yang akan dilakukan di dalamnya tertuang dalam visi dan misi organisasi. Tentunya hal ini harus sudah ditentukan sejak awal karena berkaitan dengan pembagian tugas serta bentuk kerja sama yang akan dilakukan masing-masing anggota yang ada di dalamnya. Sehingga tujuan ini menjadi poin yang sangat penting dimiliki sebuah organisasi dalam mengoptimalkan kinerja yang ada di dalamnya.

Untuk bisa menjalankan sebuah organisasi secara optimal maka diperlukan kelengkapan unsur dasar dalam organisasi itu sendiri. 
Dengan adanya kelengkapan unsur tersebut maka organisasi dalam terlaksana dengan baik. Berikut beberapa unsur yang harus ada dalam organisasi adalah :

a. Anggota organisasi yang terdiri dari pemimpin yang mengatur organisasi secara umum, manajer yang mengepalai unit tertentu sesuai fungsi bidang kerjanya dan orang-orang yang bekerja di bawah manajer. Penyebutan ini biasanya disesuaikan dengan jenis organisasinya masing-masing.

b. Kerja sama menjadi bagian penting dalam sebuah organisasi, dengan adanya kerja sama yang baik maka tujuan organisasi dapat dicapai bersama-sama. Sehingga adanya tingkatan anggota akan membantu memudahkan dalam mengatur bagian kerja untuk menjalin kerja sama yang lebih baik.

c. Tujuan organisasi akan menjadi arah perjalanan organisasi tersebut dalam menentukan kegiatan yang dilakukan nantinya.

d. Lingkungan seperti kondisi sosial, budaya, ekonomi dan teknologi menjadi pendukung dalam mencapai tujuan dari organisasi yang telah ditentukan sebelumnya.

e. Peralatan adalah sarana seperti materi, budget dan barang modal lainnya yang dapat menjadi tempat bekerja atau berkumpulnya organisasi.

f. Komunikasi tentunya akan sangat mempengaruhi bagaimana setiap anggota organisasi dapat bekerjasama dengan baik. Komunikasi yang baik akan sangat mendukung perkembangan organisasi secara lebih optimal sesuai dengan proses kerja yang sudah diatur sedemikian rupa.

\section{Komunikasi organisasi}

Komunikasi organisasi adalah pengiriman dan penerimaan sebagai pesan organisasi didalam kelompok formal 
maupuninformal dari suatu organosasi (wiryanto, 2015:84). Komunikasi formal adalah komunikasi yang dsetujui oleh organisasi itu sendiri dan sifatnya ber orientasi kepentingan organisasi. Isinya berupa cara kerja didlam organisasi, produktifitas dan berbagai pekerjaan yang harus dilakukan dalam organisaasi. Misalnya : memo,kebijakan, pernyataan, jumpa pers, dan suratsurat resmi adapun komunikasi informal adalah komunikasi yang disetujui secara sosial orientasinya, bukan pada organisasi, tetapi kepada anggota secara lebih individual.

Komunikasi organisasi merupakan pengiriman dan penerimaan berbagai pesan di dalam organisasi - di dalam kelompok formal maupun informal organisasi. Jika organisasi semakin besar dan semakin kompleks, maka demikian juga komunikasinya. Pada organisasi yang beranggotakan tiga orang, komunikasinya relative sederhana, tetapi organisasi yang beranggotakan seribu orang komunikasinya sangat kompleks. (Danivardiansyah,2004:32)

Menurut Goldhaber (1986) komunikasi organisasi adalah proses menciptakan dan saling menukar satu sama lain untuk mengatasi lingkungan yang tidak pasti atau yang selalu berubahubah.

Conrad (dalam tubbs dan moss,2015) mengidentifikasikan tiga komunikasi organisaasi sebagai berikut :

a. Fungsi perintah berkenaan dengan anggota-anggota organisasi mempunyai hak dan kewajiban membicarakan, menerima, menafsirkan dan bertindak atas suatu perintah. Tujuan dari fungsi perintah adalah koordinasi diantara sejumlah anggota yang bergantung dalam organisasi tersebut.

b. Fungsi relasionals berkenaan dengan komunikasi memperbolehkan anggota-anggota menciptakan dan 
mempertahankan bisnis produktif personal dengan anggota organisasi lain hubungan dalam pekerjaan mempengaruhii kinerja pekerjaan (job performance) dalam berbagai cara. Pentingnya dalam hubungan antar personal yang baik lebih terasa dalam pekerjaan ketika anda merasa bahwa banyak hubungan yang perlu dilakukan tidak anda pilih, tetapi diharuskan oleh lingkungan organisasi, sehingga hubungan menjadi kurang setabil,lebih memacu konflik, kurang ditaati, dan sebagainya.

c. Fungsi manajemen ambigu berkenaan dengan pilihan dalam situasi organisasi sering dibuat dalam keadaan yang sangat ambigu. Misal : motivasi berganda miuncul karena pilihan yang diambil akan mempengaruhi rekan kerja dan organisasi, demikian juga diri sendiri., tujuan organisasi tidak jelas dan konteks yang mengharuskan adanya pilihan tersebut mungkin tidak jelas. Komunikasi adalah alat untuk mengatasi dan mengurangi ketidak jelasan (ambiguity) yang melekat dalam organisasi. Anggota berbicara satu dengan lainnya untuk membangun lingkungan dan memahami situasi baru yang membutuhkan perolehan informasi bersama.

Adapun Pengaruh Komunikasi Terhadap perilaku organisasi digambarkan sebagai berikut: sebagai komunikator, seorang pemimpin organisasi, manajer, atau administrator harus memilih salah satu berbagai metode dan tehnik komunikasi yang disesuaikan dengan situasi pada waktu komunikasi di lancarkan. Sebagai komunikator, seorang manajer harus menyesuaikan penyampaian pesannya kepada peranannya yang sedang dilakukannya. Dalam hubugan ini, Henry Mint Zberg dalam Ngalimun (2017:85) menyatakan wewenang formal seorang manajer menyebabkan timbulnya tiga peranan: 


\section{Pola Komunikasi Organisasi}

Pola Komunikasi Organisasi Meskipun semua organisasi harus melakukan komunikasi dengan berbagai pihak untuk mencapai tujuannya, pendekatan yang dipakai antara satu organisasi dengan organisasi yang lain bervariasi atau berbeda-beda.Untuk organisasi berskala kecil mungkin pengaturannya tidak terlalu sulit sedangkan untuk organisasi besar yang memiliki banyak anggota maka penyampaian informasi kepada mereka menupakan pekerjaan yang cukup rumit. Untuk itu, menentukan suatu pola komunikasi yang tepat dalam suatu organisasi merupakan suatu keharusan. Terdapat dua macam jaringan komunikasi organisasi (Muhammad, 1995:102), yaitu :

1. Jaringan Komunikasi Formal Dalam struktur garis, fungsional maupun matriks, nampak berbagai macam posisi atau kedudukan yang masing-masing sesuai batas dan tanggung jawab dan wewenangnya. Dalam kaitannya dengan proses penyampaian informasi dari pimpinan kepada bawahan ataupun dari para manajer kepada karyawannya, pola transformasinya dapat berbentuk down ward communication ,upward communication, horizontal communication dan diagonal communication.

Komunikasi dari atas ke bawah menupakan aliran komunikasi dari atasan ke bawahan, di mana umumnya terkait dengan tanggung jawab dan wewenang seseorang dalam suatu organisasi. ada lima tujuan pokok yaitu:Memberi pengarahan atau instruksi kerja.

1. Memberi informasi mengapa suatu pekerjaan harus dilaksanakan.

2. Memberi informasi tentang prosedur dan praktik organizational. 
3. Memberi umpan balik pelaksanaan kerja kepada karyawan.

4. Menyajikan informasi mengenai aspek ideologi yang dapat membantu organisasi menanamkan pengertian tentang tujuan yang ingin dicapai.

2. Jaringan Komunikasi Informal Dalam jaringan komunikasi informal orang-orang yang ada dalam suatu organisasi baik secara jenjang hirarki, pangkat dan kedudukan atau jabatan dapat berkomunikasi secara leluasa. Namun jenis komunikasi ini karena sifatnya yang umum, informasi yang diperoleh seringkali kurang akurat dan tidak dapat dipertanggungjawabkan kebenarannya, karena biasanya lebih bersifat pribadi atau bahkan sekadar desas-desus.

Di dalam jaringan komunikasi informal ini, tentunya ada berbagai macam informasi yang mengalir. Namun ada dua tipe informasi yang paling utama atau paling sering menjadi pembicaraan utama dalam komunikasi informal dalam suatu organisasi, yakni: gosip dan rumor. Pola jaringan komunikasi informal sangat penting bagi organisasi namun bila proses pelaksanaannya tidak efektif bisa memberikan kerugian seperti dari sisi individual sering membuat frustasi atau menjengkelkan pihak tertentu khususnya tentang keterbatasan untuk masuk ke dalam proses pengambilan keputusan.

Dimana banyak jalur yang harus dimasuki atau dilewati sebelum langsung ke pengambilan keputusan. Dari sisi perusahaan kemungkinan munculnya distorsi atau gangguan penyampaian informasi ke level yang lebih tinggi, karena setiap keterkaitan jaringan (link) dalam jalur komunikasi dapat menggambarkan suatu kemungkinan munculnya kesalah pahaman.

2. Teori Komunikasi Organisasi 
Teori Intergratif yang dikemukakan oleh Richard Farace, Peter Monge, dan Hamish Russel (dadang,kahmad.2012:188) menunujukkan pandangan umum yang sangat menratik mengenai konsep dari organisasi. Karya mereka merupakan integrasi dari berbagai gagasan terbaik kedalam suatu bentuk yang secara intemal telah memberikan suatu sintetis mengenai pandangan sistem. Sebagai tambahan, karya mereka juga mnyatukan sejumlah besar pemikiran yang didasarkan oleh peeliltian dan mereka menempatkan komunikasi sebagai pusat dari strukutur organisasi. Mereka mendefinisikan organisasi sebagai suatu siste yang terdiri atas dua orang (atau lebih), ada saling ketergantungan, input, proses, dan output. Kelompok ini berkomuikasi dan bekerja sama untuk menghasilkan output dengan menggunakan energi, informasi dan bahan lain.

Salah satu sumber daya penting dalam organisasi adalh informasi. Dengan menggunakan teori informasi sebagai dasar, Parace dan rekannya mendefinisikan informasi dalam pengertian untuk mengurangi ketidak pastian. Ketika orang mampu memperkirakan pola-pola yang terjadi dalam aliran tugas dan hubungannya, ketidakpastian dapat dikurangi dan informasi berhasil diperoleh. Komunikasi merupakan pengurai ketidakpastian melalui informasi karena komuikasi mencakup penggunaan "Bentuk-bentuk simbolis" umum yang saling dimengerti partisannya.

Dalam teorinya, mereka mengemukakan dua bentuk komunikasi yang berkaitan dengan dua bentuk informasi yaitu

1 Informasi absolut yaitu keseluruhan informasi yang dikomunikasikan dalam suatu organisasi. Informasi ini terdiri atas keping pengetahuan yang ada dalam sistem. 
2. Informmasi yang didistribusikan adlaah informasi yang telah disebarkan melalui onganisasi.

Informasi yang ada dalam suatu organisasi tidak menjamin bahwa informasi tersebut cukup dikomunikasikan didalam sistem. Pertanyaan mengenai absolut berkenaan dengan apa yang diketahui, sedangkan pertanyaan mengenai informasi distribusi berkenaan dengan siapa yang mengetahuinya. Implikasi praktis dari perbedaan teoritis ini adalah bahwa kegagalan dalam kebijakan distribusi informasi disebabkan oleh kegagalan manajer.

Kerangka struktural fugsional bagi komunikasi organi sasi terletak pada dimensi analitis, yang terdiri atas :

a.

Level Sistem, yang terdiri atas empat sub level yaitu : individual, dyadic, kelompok dan organisasional dalam suatu prinsip hierarki sistem.

b.

Level Analisis, pada setiap level analisis, kita dapat mengamati fugsi komunikasi sekaligus analisis dimensi yang kedua. Diantara berbagai fungsi komunikasi yang ada, farace menekankan pada tiga fungsi : a. Produksi yang mengacu pada koordinasi kontrol terhadap aktifitas organisasi b. Inovasi yang membangkitkan atau mendorong perubahan dan gagasan baru dalam sistem c. Pemeliharaan untuk melindungi nilai-nilai individual dan hubungan antar pribadi yang dibutuhkan antar sistem.

C.

Dimensi Struktur, jika fungsi berkaitan dengan isi pesan, struktur berkaitan dengan tumbuhnya pola-pola atau aturan-aturan dalam penyampaian pesan.

Konsep kunci yang berhubungan dengan komunikasi individu dalam organisasi adalah beban. Ada dua lingkup persoalan berkaitan dengan muatan tersebut yaitu : 
a. Underloat, yaitu ketika aliran pesan kepada seseorang berada dibawah kapasitas orang tersebut untuk memprosesnya.

b. Overloat, yaitu ketika muatan melampaui kapasitas.

Pengertian mengenai loat, underloat, overloat berhubungan secara optimal dengan komunikasi yang diterima individu tunggal sehingga konsep ini juga bisa diterapkan pada seluruh level lainnya, termasuk dyadic, kelompok, dan organisasional.

Konsep kunci yang dapat diterapkan pada level dyadic saling berhungan dengan aturan-aturan. Para anggota dyadic juga saling berhungan sesuai dengan pola harapan dan tuntutan, disamping aturan explisit ataupun implisit untuk berkomunikasi.

Melalui setiap hari antara anggota organisasi, individuindividu dalam berbagai kelompok cenderung untuk berkomunikasi dan berkomunikasi bersama-sama. Sejak seseorang bekerja bersama-sama dalam kelompok dan fungsi yang berbeda.

5. Karang Taruna

Karang Tarunaadalah organisasi kepemudaan di Indonesia. Karang Taruna merupakan wadah pengembangan generasi muda nonpartisan, yang tumbuh atas dasar kesadaran dan rasa tanggung jawab sosial dari, oleh dan untuk masyarakat khususnya generasi muda di wilayah Desa / Kelurahan atau komunitas sosial sederajat, yang terutama bergerak dibidang kesejahteraan sosial.Karang Taruna merupakan wadah pembinaan dan pengembangan serta pemberdayaan dalam upaya mengembangkan kegiatan ekonomis produktif dengan pendayagunaan semua potensi yang tersedia dilingkungan baik sumber daya manusia maupun sumber daya alam yang telah ada.Semua ini wujud dari pada regenerasi organisasi demi kelanjutan organisasi serta pembinaan anggota Karang Taruna baik dimasa sekarang maupun masa yang akan datang.Karang Taruna 
beranggotakan pemuda dan pemudi (dalam AD/ART nya diatur keanggotaannya mulai dari pemuda/i).

Karang Taruna didirikan dengan tujuan memberikan pembinaan dan pemberdayaan kepada para remaja, misalnya dalam bidang keorganisasian, ekonomi, olahraga, ketrampilan, advokasi, keagamaan dan kesenian.

Memaknai Karang Tanuna dalam satu sudut pandang (untuk pemuda saja) sebenarnya tidak masalah. Akan tetapi akan berdampak pada produktivitas pemuda. Pemuda hanya akan peka terhadap masalah yang berkaitan dengan kepemudaan saja. Sehingga program pemberdayaan masyarakat terfokus pada pemuda pula, tidak kepada masalah sosisal secara umum. Pada akhirnya kita sebagai pemuda akan lupa bahwa masalah anak-anak lebih banyak, masalah orangtua harus di prioritaskan. Belum lagi kita berbicara masalah persatuan. Persatuan masyarakat desa akan terbangun jika kegiatan karang taruna melibatkan semua elemen masyarakat.

Mulai saat ini masyarakat perlu memahami urgensi tugas pokok Karang Taruna. Pemahaman tersebut bisa dilakukan dengan cara melakukan sosialisai oleh pemerintah desa atau yang berperan di bidang itu. Sosialisasi bisa disajikan dalam bentuk yang menarik seperti Ngobras (Ngobrpl santai), Ngopi (Ngobrol Pemuda dan Pemudi), Nobar (Nonton Bareng) atau Mubar (Musyawarah Bareng). Setelah diberikan pemahaman, program Karang Taruna mesti diarahkan kerah pemecahan masalah sosial yang ada. Contoh Karang Taruna membuat Program Pendirian Desa Binaan Masyarakat Buta Aksara untuk masyarakat yang belum bisa membaca, Pendirian Taman Baca Anak untuk anak Desa, dan Pembinaan bekal Pra-nikah untuk para remaja dan lain-lain. Dengan demikian program kerja dan tujuan dibentuknya Karang Taruna memiliki relevansi dan diakui keberadaannya oleh pemerintah dan masyarakat. 


\section{a. Tujuan Karang Tanuna}

1. Terwujudnya pertumbuhan dan perkembangan kesadaran tanggung jawab sosial setiap generasi muda warga Karang Taruna dalam mencegah, menangkal, menanggulangi dan mengantisipasi berbagai masalah social.

2. Terbentuknya jiwa dan semangat kejuangan generasi muda warga Karang Taruna yang trampil dan berkepribadian serta berpengetahuan.

3. Tumbuhnya potensi dan kemampuan generasi muda dalam rangka mengembangkan keberdayaan warga Karang Taruna.

4. Termotivasinya setiap generasi muda Karang Taruna untuk mampu menjalin toleransi dan menjadi perekat persatuan dalam keberagaman kehidupan bermasyarakat, berbangsa dan bernegara.

5. Terjalinnya kerjasama antara generasi muda warga Karang Taruna dalam rangka mewujudkan taraf kesejahteraan sosial bagi masyarakat.

6. Terwujudnya kesejahteraan sosial yang semakin meningkat bagi generasi muda di desa/kelurahan atau komunitas adat sederajat yang memungkinkan pelaksanaan fungsi sosialnya sebagai manusia pembangunan yang mampu mengatasi masalah kesejahteraan sosial dilingkungannya.

7. Terwujudnya pembangunan kesejahteraan sosial generasi muda di desa/kelurahan atau komunitas adat sederajat yang dilaksanakan secara komprehensif, terpadu dan terarah serta berkesinambungan oleh Karang Taruna bersama pemerintah dan komponen masyarakat lainnya.

\section{b. Tugas Pokok Karang Taruna}

Secara bersama sama dengan Pemerintah dan komponen masyarakat lainnya untuk menanggulangi berbagai masalah kesejahteraan sosial terutama yang dihadapi generasi muda, baik yang

76 | Efek Komunikasi Dalam Organisasi Karang Taruna Agus Baihaqi, Rizqi Martino 
bersifat preventif (bersifat mencegah), rehabilitatif (bersifat memperbaiki) maupun pengembangan potensi generasi muda di lingkungannya.

c. Fungsi Karang Taruna adalah

1. Penyelenggara Usaha Kesejahteraan Sosial.

2. Penyelenggara Pendidikan dan Pelatihan bagi masyarakat.

3. Penyelenggara pemberdayaan masyarakat terutama generasi muda secara komprehensif, terpacu dan terarah serta berkesinambungan.

4. Penyelenggara kegiatan pengembangan jiwa kewirausahaan bagi generasi muda di lingkungannya.

5. Penanaman pengertian, memupuk dan meningkatkan kesadaran tanggung jawab sosial generasi muda.

6. Penumbuhan dan pengembangan semangat kebersamaan, jiwa kekeluargaan, kesetiakawanan sosial dan memperkuat nilai-nilai kearifan dalam bingkai Negara Kesatuan Republik lndonesia.

7. Pemupukan kreatifitas generasi muda untuk dapat mengembangkan tanggung jawab sosial yang bersifat rekreatif, kreatif, edukatif, ekonomis produktif dan kegiatan praktis lainnya dengan mendayagunakan segala sumber dan potensi kesejahteraan sosial di lingkungannya secara swadaya.

8. Penyelenggara rujukan, pendampingan, dan advokasi sosial bagi penyandang masalah kesejahteraan sosial.

9. Penguatan sistem jaringan komunikasi, kerjasama, informasi dan kemitraan dengan berbagai sektor lainnya.

10. Penyelenggara Usaha usaha pencegahan permasalahan sosial yang aktual.

\section{Kesimpulan}

Dari paparan diatas maka dapat ditemukan Efek KomunikasiDalam Organisasi Karang Taruna adalah sebagai pemersatu warga 
Sumberkembang Barat, dan menjaga kearifan lokal masyarakat desa yaitu gotong royong.

\section{DAFTAR PUSTAKA}

Soerjono,Soekanto.1982.sosiologi suatu pengantar. Jakarta:CV. Rajawali. Ngalimun.2017.ilmu komunikasi.Yogyakarta:PUSTAKA BARU PRESS.

Arifin, Noor. 2007. Ilmu Sosial Dasar. Bandung: CV. Pustaka Setia. Effendy, Uchjana Onong. 2004. Ilmu Komunikasi Teori dan Prkatek. Bandung: PT. Remaja Rosdakarya.

Effendy, Onong Uchjana. (2003). Ilmu, teori dan filsafat komunikasi. Bandung :

Citra Aditya Bakti

Mulyana Deddy. 2005. Ilmu Komunikasi Suatu Pengantar. Bandung: PT Remaja

Rosdakarya

Agus M. Hardjana. 2003. Komunikasi intrapersonal \& Komunikasi Interpersonal. Yogyakarta: Penerbit Kanisius

Sendjaja, S. Djuarsa. 1999. Teori Komunikasi. Universitas Terbuka. Jakarta.

Dalam Imam Gunawan. 2015. METODE PENELITIAN KUALITATIF: Teori dan Praktik. Jakarta: Bumi Aksara.

Lexy J. Moleong, Metodologi Penelitian Kualitatif (Bandung: PT. Remaja Rosdakarya, 2015).

Sugiyono.2006.Metode Penelitian Kuantitatif, Kualitatif dan R \& D.Bandung:Alfabeta.

Mesiono.2010. Manajemen dan Organisasi, Bandung : Citapustaka Media Perintis.

Chaniago, Nasrul Syakur.2011 Manajemen Organisasi, Bandung : citapustaka Media Perintis.

Keith R. Stamm dan John E. Bowes1990The Mass Communications ProcessKendall HuntpublishingIowa

http://dickysyuhada.blogspot.com/2011/01/hakikat-organisasi.html

78 | Efek Komunikasi Dalam Organisasi Karang Taruna Agus Baihaqi, Rizqi Martino 